\title{
Master of Health Services Administration
}

National Cancer Institute

\section{Source}

National Cancer Institute. Master of Health Services Administration. NCI Thesaurus.

Code C39450.

Master of Health Services Administration is a master's degree in health administration and health care management. 